\title{
Family history of breast cancer increases the risk of prostate cancer: results from the EPICAP study
}

\author{
Pierre-Jean Lamy ${ }^{1,2}$, Brigitte Trétarre ${ }^{3}$, Xavier Rebillard $^{1}$, Marie Sanchez $^{4}$, Sylvie \\ Cénée ${ }^{4}$ and Florence Ménégaux ${ }^{4}$ \\ ${ }^{1}$ Service Urologie, Clinique Beau Soleil, Montpellier, France \\ ${ }^{2}$ Institut d'Analyse Génomique-Imagenome, Labosud, Montpellier, France \\ ${ }^{3}$ Registre des Tumeurs de I'Hérault, ICM, Montpellier, France \\ ${ }^{4}$ Université Paris-Saclay, Université Paris-Sud, CESP (Center for Research in Epidemiology and Population Health), Inserm, \\ Team Cancer and Environment, Villejuif, France
}

Correspondence to: Pierre-Jean Lamy, email: pierre-jean.lamy@labosud-ocbiologie.fr

Keywords: family history of cancer; epidemiology; prostate cancer; breast cancer; Gleason score

Abbreviations: BCa: breast cancer; GS: Gleason score; OR: Odd ratio; PCa: prostate cancer

Received: March 01, $2018 \quad$ Accepted: April 17, $2018 \quad$ Published: May 04, 2018

Copyright: Lamy et al. This is an open-access article distributed under the terms of the Creative Commons Attribution License 3.0 (CC BY 3.0), which permits unrestricted use, distribution, and reproduction in any medium, provided the original author and source are credited.

\section{ABSTRACT}

Introduction: Familial aggregation is now well established with an increased risk of prostate cancer in patients with a family history of prostate cancer in first degree relatives. The aim of this paper was to investigate the role of family history of cancer in first degree relatives in prostate cancer risk.

Results: As expected, a family history of prostate cancer in first-degree relatives was more frequent in cases than in controls (OR 3.10, 95\% CI 2.32-4.15). A family history of early BCa (before age 50 ) in first-degree relatives was more frequent in cases than in controls (OR 1.79, 95\% CI 1.09-2.94) with higher risk of aggressive PCa. The association was more pronounced for BCa in daughters (OR 15.26 95\% CI 1.95-120).

Conclusions: In summary, a family history of $\mathrm{BCa}$ in first degree relatives before age $\mathbf{5 0}$ may increases the risk of PCa with higher Gleason score. This finding could suggest a specific prostate surveillance and/or genetic counselling for men who present such familial history.

Methods: EPIdemiological study of Prostate CAncer (EPICAP) is a population-based case-control study specifically designed to investigate the role of environmental and genetic factors in prostate cancer. Detailed information on family history of cancer in first degree relatives (parents, brothers and sisters, children) was collected as well as the age of occurrence and the localization of each cancer. Overall, 819 cases and 879 controls have been included.

\section{INTRODUCTION}

In most Western countries, prostate cancer $(\mathrm{PCa})$ is by far the most commonly diagnosed cancer in men, which represents, in France, an estimated 53,917 new cases and 8,685 deaths in 2011 [1]. Despite a relatively high morbidity and mortality (3rd leading cause of cancer death in France), only age, ethnicity and a family history of $\mathrm{PCa}$ are well-established risk factors of $\mathrm{PCa}$, and except those factors, the aetiology of $\mathrm{PCa}$ remains largely unknown.
Familial aggregation is now well established with an increased risk of $\mathrm{PCa}$ in patients with a family history of PCa in the first-degree relatives [2-6]. This risk is even more important if the affected relative is a brother and if the number of relatives affected is large [7, 8]. Family studies have also shown that some PCas can be inherited as an autosomal dominant model and it has been estimated that PCa family, due to a rare gene with high penetrance, accounted for approximately $10 \%$ of all PCa [9] Recently, genome-wide association studies have identified at 
least 100 susceptibility loci associated with $\mathrm{PCa}$ [10]. Individually, they contribute to a small increase in $\mathrm{PCa}$ risk but taken together approximately $30 \%$ of the familial risk is due to such variants.

If it is known that prostate cancer can run in families, it is not known whether other cancers are frequent in such families. Recently, familial associations between PCa and other cancers has been studied in a Swedish cohort suggesting that breast, kidney, nervous system tumors and myeloma occur more often in families of PCa patients [11]. In that context of a possible familial risk, there is growing evidence for clustering of breast and prostate cancer and that breast cancer family history may also influence prostate cancer risk. [12-17].

The aim of this paper was to investigate the role of family history of cancer in first-degree relatives, based on data from the French EPICAP study.

\section{RESULTS}

The characteristics of the study population are presented in Table 1. Age in 5-year groups, ethnic origin, educational level, smoking status and body mass index were similarly distributed between cases and controls $(p=0.14$, $p=0.23, p=0.37, p=0.08, p=0.91$, respectively).

As expected in the literature, a family history of $\mathrm{PCa}$ in first-degree relatives was more frequent in cases than in controls (OR 3.10, 95\% CI 2.32-4.15) (Table 2). In addition, the risk was more pronounced according to the number of family history of $\mathrm{PCa}$ in first-degree relatives ( $p$ trend $<0.001$ ) and for early PCa in relatives (less than 60 years at time of diagnostic), either in father or in brothers (OR 4.04, 95\% CI 1.60-10.2, OR 5.91, 95\% CI 2.66-13.1, respectively).

A family history of early $\mathrm{BCa}$ (before age 50 ) in firstdegree relatives was more frequent in cases than in controls (OR 1.79, 95\% CI 1.09-2.94) which was not observed for family history of BCa after 50 years (OR $0.88,95 \%$ CI 0.61-1.27. (Table 3). The number of family history of $\mathrm{BCa}$ and a family history of $\mathrm{BCa}$ in sisters or in mothers, whatever the age at diagnosis of cancer, were not associated with the risk of PCa. However, $\mathrm{BCa}$ in daughters was significantly associated with higher risk of PCa (OR 15.26 95\% CI 1.95-120), even though based on small numbers. Looking at the associations between family history of $\mathrm{BCa}$ and $\mathrm{PCa}$ risk according to family history of $\mathrm{PCa}$, only $\mathrm{BCa}$ in daughers in family with no history of PCa are relevant (OR 14.6 95\% CI 1.85-116) (Table 4).

A family history of $\mathrm{BCa}$ before age 50 in a firstdegree relative was more specifically associated with aggressive PCa (OR 2.42 95\% CI 1.19-4.90). In the sub-class of family history in daughters, the risk was higher for aggressive $\mathrm{PCa}$ than for low or intermediate PCa (OR 9.25 95\% CI 1.66-51.6, OR 5.64 95\% CI 1.16-27.5, respectively), even though the difference was not statistically different. $(p=0.42)$ (Table 5).
We did not observed any association between $\mathrm{PCa}$ and family history of other cancer localizations in firstdegree relatives (data not shown).

\section{DISCUSSION}

The EPIdemiological study of Prostate CAncer (EPICAP) is a large population-based case-control study specifically carried out to investigate the role of environmental and genetic factors in prostate cancer. In concordance with previous studies, we showed that family history of PCa in first-degree relatives was associated with higher PCa risk [12-15].

We also showed a strong association between family history of $\mathrm{BCa}$ in first-degree relatives and $\mathrm{PCa}$ risk, particularly when $\mathrm{BCa}$ in first-degree relatives was before the age of 50. This association was also more pronounced for aggressive $\mathrm{PCa}$. It has been previously shown that the relative risk for $\mathrm{PCa}$ was higher with four or more affected family members with any cancers [18]. On another way, the relationship between $\mathrm{BCa}$ and $\mathrm{PCa}$ have been already described in epidemiological studies based on $\mathrm{BCa}$ populations. In an Iceland cohort of women with $\mathrm{BCa}$, an increased risk of $\mathrm{PCa}$ among relatives (particularly for first degree relatives) has been described [19]. Recently, findings suggest that $\mathrm{PCa}$ diagnosed among first-degree family members increases a woman's risk of developing $\mathrm{BCa}$. However, different results were shown for male BCa and risk of PCa. [20, 21]. Those data and our findings data complement one another to assume a global familial risk of $\mathrm{BCa}$ and $\mathrm{PCa}$.

Considering the cause of that segregation, many hypotheses have been suggested for those hormone-related cancers. Highly penetrance gene was suspected for this linkage. For PCa and ovarian cancer, a BRCA2 mutation accounts for most of the familiarity observed in families of $\mathrm{BCa}$ patients [19]. BRCA2 is a tumor suppressor gene. It helps repair DNA double strand damage and, therefore, play a role in ensuring the stability of the cell's genetic material. Specific inherited mutations in BRCA2 increase the risk of female breast and ovarian cancers. It has been also associated with increased risks of several additional types of cancer like PCa. Six percent of men with castration-resistant $\mathrm{PCa}$ could have pathogenic germline mutations of BRCA2 [22]. Our finding suggests a possible role of altered genes that could increase risk of cancers by common mechanisms like DNA repair leading to aggressive cancer in accordance with the linkage for PCa with higher Gleason score we founded [23]. Epidemiological studies indicate that dominantly inherited susceptibility genes with high penetrance may cause up to $5 \%$ to $10 \%$ of all PCa cases. Looking at common high penetrance alleles, several linkage studies for PCa have been completed, often with conflicting results [24, 25]. Then, using NGS in large studies with thousands of men, $H O X B 13$-variant Gly84Glu was a validated gene associated with PCa [26]. However, this 
Table 1: Study population characteristics

\begin{tabular}{|c|c|c|c|}
\hline & $\begin{array}{c}\text { Cases } \\
n=819(\%)\end{array}$ & $\begin{array}{c}\text { Controls } \\
n=879(\%)\end{array}$ & $p$-value ${ }^{1}$ \\
\hline \multicolumn{4}{|l|}{ Gleason score at diagnosis ${ }^{2}$} \\
\hline$<7$ & $341(41.6)$ & - & \\
\hline 7 (including $3+4$ ) & $282(34.4)$ & - & \\
\hline$>7$ (including $4+3$ ) & $183(22.3)$ & - & \\
\hline Age (years) & & & 0.14 \\
\hline$<55$ & $48(5.9)$ & $59(6.7)$ & \\
\hline$[55-60]$ & $99(12.1)$ & $99(11.3)$ & \\
\hline$[60-65]$ & $217(26.5)$ & $201(22.9)$ & \\
\hline$[65-70]$ & $274(33.5)$ & $285(32.4)$ & \\
\hline$\geq 70$ & $181(22.1)$ & $235(26.7)$ & \\
\hline Ethnic Origin & & & 0.23 \\
\hline Caucasian & $795(97.1)$ & $859(97.7)$ & \\
\hline Others & $24(2.9)$ & $20(2.3)$ & \\
\hline Educational level & & & 0.37 \\
\hline Middle school & $70(8.5)$ & $72(8.2)$ & \\
\hline Up to high school & $376(45.9)$ & $436(49.7)$ & \\
\hline High school & $113(13.8)$ & $110(12.5)$ & \\
\hline College & $260(31.7)$ & $260(29.6)$ & \\
\hline Body Mass Index (kg/m²) & & & 0.91 \\
\hline$<25$ & $297(36.8)$ & $316(36.6)$ & \\
\hline$[25-30]$ & $377(46.7)$ & $395(45.8)$ & \\
\hline$\geq 30$ & $134(16.5)$ & $152(17.7)$ & \\
\hline Smoking status & & & 0.08 \\
\hline Never & $240(29.3)$ & $246(28.0)$ & \\
\hline Former & $455(55.6)$ & $476(54.2)$ & \\
\hline Curent & $123(15.0)$ & $157(17.9)$ & \\
\hline Number of first degree relatives & & & 0.026 \\
\hline 2 to 5 & $289(35.6)$ & $263(30.0)$ & \\
\hline 6 to 9 & $421(51.8)$ & $473(54.1)$ & \\
\hline$\geq 10$ & $103(12.6)$ & 139 (15.9) & \\
\hline
\end{tabular}

${ }^{1}$ Adjusted for age (except for age).

${ }^{2}$ Category " Gleason $=7$ » includes subjects for whom the two most commonly represented grades in the tumor are not known, as well as those for which the two grades are $3+4$. Category « Gleason $>7$ » includes subjects for whom the sum of the two most frequently represented grades in the tumor analyzed is $>7$ and those for which the two grades are $4+3$.

gene seems not to be implicated in BCa. Finally, common genetics variants, in genome wide association studies (GWAS), led to determine at least 100 SNP associated with a part of PCa risk [10]. It is also possible that those variants could have an impact on $\mathrm{BCa}$.

Shared environmental risk factors could also contribute to the risks for cancers, even for cancer that could be driven by same genetic predisposition. The role of endocrine disruptors in hormone-related cancers (breast, prostate, testicular) is currently studied and could be another hypothesis to explain this association $[27,28]$.

Our results are based on a large population-based case-control study carefully designed to assess the role of environmental and genetic factors in prostate cancer occurrence. We were able to confirm that we identified all eligible cases over the study period by a posteriori crosschecking of the identified list of eligible cases with that of the Hérault cancer registry. Moreover, even though participation 
Table 2: Associations between family history of prostate cancer (PCa) and prostate cancer risk

\begin{tabular}{|c|c|c|c|}
\hline & $\begin{array}{c}\text { Cases } \\
n=819(48.2 \%)\end{array}$ & $\begin{aligned} & \text { Controls } \\
n= & 879(51.8 \%)\end{aligned}$ & $\mathrm{OR}^{1} 95 \% \mathrm{CI}^{2}$ \\
\hline \multicolumn{4}{|c|}{ Family history of PCa in first degree relatives } \\
\hline No & $549(75.2)$ & $723(90.4)$ & 1.00 reference \\
\hline Yes & $181(24.8)$ & $77(9.6)$ & $3.10(2.32-4.15)$ \\
\hline Cancer $>60$ years & $126(17.4)$ & $64(8.0)$ & $2.57(1.86-3.54)$ \\
\hline Cancer $<60$ years & $49(6.8)$ & $13(1.6)$ & $5.15(2.75-9.62)$ \\
\hline \multicolumn{4}{|c|}{ Number of family history of PCa in first degree relatives } \\
\hline None & $549(75.2)$ & $723(90.4)$ & 1.00 reference \\
\hline 1 & $159(21.8)$ & $70(8.8)$ & $2.98(2.20-4.03)$ \\
\hline \multirow[t]{2}{*}{$\geq 2$} & $22(3.0)$ & $7(0.9)$ & $4.44(1.87-10.6)$ \\
\hline & & & $p$ trend $<0.001$ \\
\hline \multicolumn{4}{|c|}{ Family history of PCa in fathers } \\
\hline No & $549(75.2)$ & $723(90.4)$ & 1.00 reference \\
\hline Yes & $127(18.8)$ & $57(7.3)$ & $2.85(2.04-3.98)$ \\
\hline Cancer $>60$ years & $104(15.5)$ & $51(6.5)$ & $2.60(1.82-3.71)$ \\
\hline Cancer $<60$ years & $19(2.8)$ & $6(0.8)$ & $4.04(1.60-10.2)$ \\
\hline \multicolumn{4}{|c|}{ Family history of $\mathrm{PCa}$ in brothers } \\
\hline No & $549(75.2)$ & $723(90.4)$ & 1.00 reference \\
\hline Yes & $65(46.7)$ & $27(45.8)$ & $3.79(2.36-6.10)$ \\
\hline Cancer $>60$ years & $33(16.5)$ & $18(17.7)$ & $2.73(1.51-4.91)$ \\
\hline Cancer $<60$ years & $30(16.5)$ & $9(17.7)$ & $5.91(2.66-13.1)$ \\
\hline
\end{tabular}

${ }^{1} \mathrm{OR}$ : Odds Ratios adjusted for age, ethnic origin and number of male relatives.

295\% CI: 95\% Confidence Interval.

Table 3: Associations between family history of breast cancer (BCa) and prostate cancer risk

\begin{tabular}{|c|c|c|c|}
\hline & $\begin{array}{c}\text { Cases } \\
n=819(\%)\end{array}$ & $\begin{array}{c}\text { Controls } \\
n=879(\%)\end{array}$ & $\mathrm{OR}^{1} 95 \% \mathrm{CI}^{2}$ \\
\hline \multicolumn{4}{|c|}{ Family history of $\mathrm{BCa}$ in first degree relatives } \\
\hline No & $647(84.5)$ & $711(85.4)$ & 1.00 reference \\
\hline Yes & $119(15.5)$ & $122(14.6)$ & $1.13(0.84-1.52)$ \\
\hline Cancer $>50$ years & $63(7.7)$ & $80(9.1)$ & $0.88(0.61-1.27)$ \\
\hline Cancer $<50$ years & $45(5.5)$ & $32(3.6)$ & $1.79(1.09-2.94)$ \\
\hline \multicolumn{4}{|c|}{ Number of family history of $\mathrm{BCa}$ in first degree relatives } \\
\hline None & $647(84.5)$ & $711(85.4)$ & 1.00 reference \\
\hline 1 & $109(14.2)$ & $110(13.2)$ & $1.11(0.82-1.51)$ \\
\hline \multirow[t]{2}{*}{$\geq 2$} & $10(1.3)$ & $12(1.4)$ & $1.38(0.55-3.43)$ \\
\hline & & & $p$ trend $=0.36$ \\
\hline \multicolumn{4}{|c|}{ Family history of $\mathrm{BCa}$ in mothers } \\
\hline No & $647(84.5)$ & $711(85.4)$ & 1.00 reference \\
\hline Yes & $62(8.7)$ & $69(8.8)$ & $1.04(0.71-1.52)$ \\
\hline Cancer $>50$ years & $42(5.9)$ & $53(6.8)$ & $0.95(0.61-1.48)$ \\
\hline Cancer $<50$ years & $20(2.8)$ & $15(1.9)$ & $1.39(0.67-2.87)$ \\
\hline \multicolumn{4}{|c|}{ Family history of $\mathrm{BCa}$ in sisters } \\
\hline No & $647(84.5)$ & $711(85.4)$ & 1.00 reference \\
\hline Yes & $55(7.8)$ & $60(7.8)$ & $1.10(0.72-1.68)$ \\
\hline
\end{tabular}



Cancer $>50$ years
$25(3.2)$
$32(3.6)$
$0.87(0.49-1.54)$
Cancer $<50$ years
$16(2.0)$
$16(1.8)$
$1.36(0.65-2.85)$
Family history of BCa in daughters
$647(84.5)$
$711(85.4)$
1.00 reference
$11(1.7)$
$2(0.3)$
$15.26(1.95-120)$

No

Yes

${ }^{1}$ OR: Odds Ratios adjusted for age, ethnic origin, number of first-degree female relatives and famili history of prostate cancer in first-degree relatives.

${ }^{2} 95 \%$ CI: 95\% Confidence Interval.

Table 4: Associations between family history of breast cancer and prostate cancer risk according to family history of prostate cancer

\begin{tabular}{|c|c|c|c|c|c|c|}
\hline & \multicolumn{3}{|c|}{ No family history of prostate cancer } & \multicolumn{3}{|c|}{ Family history of prostate cancer } \\
\hline & $\begin{array}{c}\text { Cases } \\
n=549(\%)\end{array}$ & $\begin{array}{c}\text { Controls } \\
n=423(\%)\end{array}$ & $\mathrm{OR}^{1} 95 \% \mathrm{CI}^{2}$ & $\begin{array}{c}\text { Cases } \\
n=181(\%)\end{array}$ & $\begin{array}{c}\text { Controls } \\
n=77(\%)\end{array}$ & $\mathrm{OR}^{1} 95 \% \mathrm{CI}^{2}$ \\
\hline \multicolumn{7}{|c|}{ Family history of $\mathrm{BCa}$ in first degree relatives } \\
\hline No & $448(84.1)$ & $595(84.9)$ & 1.00 reference & $150(85.7)$ & $65(89.0)$ & 1.00 reference \\
\hline Yes & $85(15.9)$ & $106(15.1)$ & $1.10(0.81-1.51)$ & $25(14.3)$ & $8(11.0)$ & $1.39(0.57-3.35)$ \\
\hline \multicolumn{7}{|c|}{ Family history of $\mathrm{BCa}$ in mothers } \\
\hline No & $448(84.1)$ & $595(84.9)$ & 1.00 reference & $150(85.7)$ & $65(89.0)$ & 1.00 reference \\
\hline Yes & $46(9.3)$ & $59(9.0)$ & $1.03(0.68-1.55)$ & $13(8.0)$ & $5(7.1)$ & $1.18(0.39-3.58)$ \\
\hline \multicolumn{7}{|c|}{ Family history of $\mathrm{BCa}$ in sisters } \\
\hline No & $448(84.1)$ & $595(84.9)$ & 1.00 reference & $150(85.7)$ & $65(89.0)$ & 1.00 reference \\
\hline Yes & $36(7.4)$ & $52(8.0)$ & $1.03(0.65-1.63)$ & $13(8.0)$ & $4(5.8)$ & $1.6(0.48-5.66)$ \\
\hline \multicolumn{7}{|c|}{ Family history of $\mathrm{BCa}$ in daughters } \\
\hline No & $448(84.1)$ & $595(84.9)$ & 1.00 reference & $150(85.7)$ & $65(89.0)$ & 1.00 reference \\
\hline Yes & $10(2.2)$ & $1(0.2)$ & $14.6(1.85-116)$ & $1(0.7)$ & $0(0.0)$ & - \\
\hline
\end{tabular}

${ }^{1}$ OR: Odds Ratios adjusted for age, ethnic origin and number of first-degree female relatives.

${ }^{2} 95 \%$ CI: 95\% Confidence Interval.

rate in cases was $75 \%$, the age distribution and the Gleason score were comparable to those of the Hérault Cancer Registry for the years 2009-2011 (private communication) which indicates that cases included in the study were representative of all eligible cases. Controls were randomly selected from the general population of the département of Hérault using quotas on age (5-years). In addition, we established quotas by socioeconomic status (SES) to yield the control group similar to the general population of the département of Hérault of the same age in terms of SES. We compared the distribution by SES between our control group and the male general population of the département of Hérault and found no significant difference, indicating that no major selection bias by SES had occurred.

To minimize recall and misclassification bias, data were collected by a trained research clinical nurse using a standardized questionnaire. Cases and controls were asked to describe all their first-degree family members before asking if one of them had had a history of cancer. Our results confirmed the strong and known association between family history of prostate cancer in first-degree relatives and prostate cancer risk which give us some confidence about the relevance about the family history data that has been collected.

The number of first-degree relatives was statistically different between cases and controls with more relatives in controls than in cases $(p=0.026)$. This may have underestimate our results rather than explain them. However, all analyses have been adjusted for the number of relatives, limiting possible confusion bias.

In summary, a family history of early $\mathrm{BCa}$ in first degree may increase the risk of $\mathrm{PCa}$, with possibly higher GS. BCa in daughter are related with the highest risk of $\mathrm{PCa}$. These findings that is necessary to confirm in an independent study, may have significant implications according the role of inherited predisposition and shared environments causes of both cancers. As the contribution of a family history of $\mathrm{BCa}$ to $\mathrm{PCa}$ risk among relatives, and vice versa, has been shown, information risk for patients with family history of cancer, even if cases are described in relatives with opposite sex, is important. It pleads for wider proposals at genetic counselling and surveillance in patients with family history of cancer and particularly of $\mathrm{BCa} / \mathrm{PCa}$. 
Table 5: Associations between family history of breast cancer and prostate cancer risk according to Gleason score

\begin{tabular}{|c|c|c|c|c|c|}
\hline & \multirow[b]{2}{*}{$\begin{array}{c}\text { Controls } \\
n=879(\%)\end{array}$} & \multicolumn{2}{|c|}{$\begin{array}{c}\text { Low or intermediate grade } \\
\text { prostate cancer } \\
\text { Gleason score } \leq 7(3+4)\end{array}$} & \multicolumn{2}{|c|}{$\begin{array}{c}\text { High grade } \\
\text { prostate cancer } \\
\text { Gleason score } \geq 7(4+3)\end{array}$} \\
\hline & & $\begin{array}{c}\text { Cases } \\
n=623(\%)\end{array}$ & $\mathrm{OR}^{1} 95 \% \mathrm{CI}^{2}$ & $\begin{array}{c}\text { Cases } \\
n=183(\%)\end{array}$ & $\mathrm{OR}^{1} 95 \% \mathrm{CI}^{2}$ \\
\hline \multicolumn{6}{|c|}{$\begin{array}{l}\text { Family history of } \mathrm{BCa} \text { in } \\
\text { first degree relatives }\end{array}$} \\
\hline No & $711(85.4)$ & $498(85.6)$ & 1.00 reference & $138(80.2)$ & 1.00 reference \\
\hline Yes & $122(14.6)$ & $84(14.4)$ & $1.04(0.76-1.41)$ & $34(19.8)$ & $1.42(0.92-2.19)$ \\
\hline Cancer $>50$ years & $80(9.1)$ & $48(7.7)$ & $0.86(0.57-1.29)$ & $14(7.7)$ & $0.96(0.52-1.77)$ \\
\hline Cancer $<50$ years & $32(3.6)$ & $32(3.6)$ & $1.66(0.97-2.85)$ & $13(7.1)$ & $2.42(1.19-4.90)$ \\
\hline \multicolumn{6}{|c|}{$\begin{array}{l}\text { Number of family history } \\
\text { of BCa in first degree } \\
\text { relatives }\end{array}$} \\
\hline None & $711(85.4)$ & $498(85.6)$ & 1.00 reference & $138(80.2)$ & 1.00 reference \\
\hline 1 & $110(13.2)$ & $76(13.1)$ & $1.02(0.74-1.40)$ & $32(18.6)$ & $1.47(0.94-2.30)$ \\
\hline \multirow[t]{2}{*}{$\geq 2$} & $12(1.4)$ & $8(1.4)$ & $1.23(0.49-3.07)$ & $2(1.2)$ & $0.90(0.20-4.14)$ \\
\hline & & & $p$ trend $=0.74$ & & $p$ trend $=0.18$ \\
\hline \multicolumn{6}{|c|}{$\begin{array}{l}\text { Family history of } \mathrm{BCa} \text { in } \\
\text { mothers }\end{array}$} \\
\hline No & $711(85.4)$ & 498 (85.6) & 1.00 reference & $138(80.2)$ & 1.00 reference \\
\hline Yes & $69(8.8)$ & $45(8.3)$ & $0.95(0.64-1.42)$ & $16(10.4)$ & $1.21(0.68-2.17)$ \\
\hline Cancer $>50$ years & $53(6.8)$ & $31(5.0)$ & $0.91(0.56-1.48)$ & $10(5.5)$ & $1.11(0.54-2.26)$ \\
\hline Cancer $<50$ years & $15(1.9)$ & $14(2.3)$ & $1.22(0.55-2.71)$ & $6(3.3)$ & $2.24(0.81-6.20)$ \\
\hline \multicolumn{6}{|c|}{$\begin{array}{l}\text { Family history of BCa in } \\
\text { sisters }\end{array}$} \\
\hline No & $711(85.4)$ & $498(85.6)$ & 1.00 reference & $138(80.2)$ & 1.00 reference \\
\hline Yes & $60(7.8)$ & $39(7.3)$ & $1.03(0.67-1.58)$ & $16(10.4)$ & $1.39(0.76-2.54)$ \\
\hline Cancer $>50$ years & $32(3.6)$ & $21(3.4)$ & $0.87(0.47-1.61)$ & $5(2.7)$ & $0.82(0.30-2.21)$ \\
\hline Cancer $<50$ years & $16(1.8)$ & $13(2.1)$ & $1.50(0.69-3.26)$ & $3(1.6)$ & $1.11(0.31-4.02)$ \\
\hline \multicolumn{6}{|c|}{$\begin{array}{l}\text { Family history of } \mathrm{BCa} \text { in } \\
\text { daughters }\end{array}$} \\
\hline No & $711(85.4)$ & $498(85.6)$ & 1.00 reference & $138(80.2)$ & 1.00 reference \\
\hline Yes & $2(0.3)$ & $7(1.4)$ & $5.64(1.16-27.5)$ & $4(2.8)$ & $9.25(1.66-51.6)$ \\
\hline
\end{tabular}

${ }^{1}$ OR: Odds Ratios adjusted for age, ethnic origin, number of first-degree female relatives and famili history of prostate cancer in first-degree relatives.

295\% CI: 95\% Confidence Interval.

\section{MATERIALS AND METHODS}

The "EPIdemiology Prostate CAncer" (EPICAP) study has been specifically designed to investigate the role of environmental and genetic factors in PCa.

\section{Case-control selection}

EPICAP is a population-based case-control study carried out in the département of Hérault, a well delimited geographic area in the South of France. Details of the EPICAP objectives and study design have been previously described elsewhere [29].

Briefly, eligible cases were all newly diagnosed PCa cases in 2012-2013 in men under the age of 75 years old and residing in the département of Hérault at the time of diagnosis. All cases have been histologically confirmed.

The eligible controls were men randomly selected in the general population of Hérault, residing in the département of Hérault, who did not declare a PCa when 
they were included in the study and frequency matched to the cases by 5-year age group. Quotas on socioeconomic status have been defined to yield the control group comparable to the population of Hérault of the same age.

Overall, among the 1,098 eligible cases and the 1,109 eligible controls, 819 cases and 879 controls have been included in the study with a participation rate of $75 \%$ and $79 \%$, respectively.

\section{Data collection}

Cases and controls were face-to-face interviewed by an experienced research clinical nurses especially trained for this study, using a standardized computerized questionnaire that gathered detailed information on socioeconomic characteristics, personal medical history, family history of cancer, lifestyle, residential and occupational history.

Detailed information on family history of cancer in first-degree relatives (parents, brothers and sisters, children) was collected. First, we gathered information for each first-degree relative, particularly first name, year of birth and vital status. Second, cases and controls were asked, for each relative they describe, whether they may have had a cancer. In case of an affected relative, the number of cancer, the localization of each cancer based on 21 proposed localizations (leukemia, mouth, UADT, lung, oesophagus, stomach, liver, colorectal, breast, thyroid, skin, melanoma, bone, kidney, bladder, endometrial or ovarian, prostate, central nervous system, myeloma, Hodgkin disease, non-Hodgkin lymphoma, other), and the age of occurrence of each cancer was collected.

Specific medical data on prostate cancer cases were collected by the clinical research nurses from the medical records at the time of diagnosis and completed by the Hérault cancer registry (PSA value, Gleason Score, and TNM stage at diagnosis).

\section{Statistical analysis}

All analyses were performed using SAS 9.4 (SAS Inc., Cary, North Carolina).

Odds ratios (OR) and their 95\% confidence intervals (95\% CI) were estimated using an unconditional logistic regression to investigate associations between family history of $\mathrm{BCa}$ in first-degree relatives and $\mathrm{PCa}$ risk. All analyzes were systematically adjusted for age, ethnicity and family history of PCa. We also adjusted analyses for potential confounding factors such as educational level or body mass index. The family structure (number of firstdegree relatives) was also taken into account in the analyses.

All analyses were performed taking into account the aggressiveness of the tumor based on the Gleason score at diagnosis (low aggressiveness and intermediate: Gleason score $<7$ and Gleason score $=7$ including subjects for whom the two most commonly represented grades in the tumor are $3+4$, as well as those for which the two grades are not known, high aggressiveness: Gleason score $>7$ and Gleason score $=7$ including subjects for whom the sum of the two most frequently represented grades in the tumor are $4+3$ ). Analyses were also stratified on family history of $\mathrm{PCa}$ in first degree relatives.

\section{Author contributions}

Study concept and design: Florence Menegaux, Pierre-Jean Lamy, Xavier Rébillard, Brigitte Trétarre; Acquisition of data: Pierre-Jean Lamy Xavier Rébillard, Brigitte Trétarre, Florence Menegaux; Data managment: Sylvie Cénée, Marie Sanchez; Statistical analysis: Sylvie Cénée, Marie Sanchez; Analysis and interpretation of data: Pierre-Jean Lamy, Marie Sanchez, Florence Menegaux; Drafting of the manuscript: Pierre-Jean Lamy, Florence Menegaux.

\section{ACKNOWLEDGMENTS}

We would like to thank the clinical research nurses who were in charge of participants' interview, anthropometric measurements and biological sample collection (Anne-Laure Astolfi, Coline Bernard, Oriane Boyer, Marie-Hélène De Campo, Sandrine Margaroli, Louise N'Diaye, Sabine Perrier-Bonnet). We also would like to thank Christian Prad and Nadine Soller for help with patient medical data collection within the Hérault Cancer Registry (Registre des tumeurs de l'Hérault, Montpellier, France). Finally, we are grateful to the EPICAP study Group:

Urologists: Drs Didier Ayuso (Centre Hospitalier Bassin de Thau, Sète, France), Alain Guillaume, JeanPaul Constans, François Iborra, Pierre Lanfray, Damien Rizet, Etienne Cuénant (Cabinet Urologie du Polygone, Montpellier, France), Michel Locci (Centre Hospitalier, Béziers, France), Etienne Cuénant (Clinique Ste Thérèse, Sète, France), Nicolas Drianno, Bernard Marc, JeanPierre Bringer (Polyclinique Saint Privat, Béziers, France), Antoine Faix, Samer Abdel Hamid, Bruno Segui (Service urologie, Clinique Beau Soleil, Montpellier, France), Samer Abdel Hamid (Clinique Saint Louis, Ganges, France), Laurent Cabaniols, Maxime Robert, Thibaut Murez (Centre Hospitalo-Universitaire, Hôpital Lapeyronie, Montpellier, France).

Pathologists: Drs Didier Brel, Lysiane Schweizer, Philippe Nayraud, C. Lecam-Savin (Béziers), Roland Daniel, Jean Baptiste Perdigou, Chantal Compan, Mireille Granier, Jean Louis Bouzigues, Elisabeth Broquerie, Joëlle Simony, Frédéric Bibeau, Pierre Baldet, Isabelle Serre (Montpellier), Marie Laure Gaume (Sète).

Biologists: Drs Montels (Service de Biologie Médicale, Institut du Cancer de Montpellier, Montpellier, France), Dumas (Béziers, France), Buono (Sète, France), 
Bonnefille (Lodeve, France), Ruiz (Lunel, France), Paleirac (Clermont-l'Hérault, France).

\section{CONFLICTS OF INTEREST}

None.

\section{FUNDING}

The EPICAP study has been funded by grants from Ligue nationale contre le cancer, Ligue contre le cancer du Val de Marne, Fondation de France, Agence nationale de sécurité sanitaire de l'alimentation, de l'environnement et du travail (ANSES).

\section{REFERENCES}

1. Grosclaude P, Belot A, Daubisse Marliac L, Remontet L, Leone N, Bossard N, Velten M. [Prostate cancer incidence and mortality trends in France from 1980 to 2011]. [Article in French]. Prog Urol. 2015; 25:536-42. https://doi. org/10.1016/j.purol.2015.04.011.

2. Narod SA, Dupont A, Cusan L, Diamond P, Gomez JL, Suburu R, Labrie F. The impact of family history on early detection of prostate cancer. Nat Med. 1995; 1:99-101.

3. Makinen T, Tammela TL, Stenman UH, Maattanen L, Rannikko S, Aro J, Juusela H, Hakama M, Auvinen A. Family history and prostate cancer screening with prostatespecific antigen. J Clin Oncol. 2002; 20:2658-63. https:// doi.org/10.1200/JCO.2002.05.006.

4. Steinberg GD, Carter BS, Beaty TH, Childs B, Walsh PC. Family history and the risk of prostate cancer. Prostate. 1990; 17:337-47.

5. Cussenot O, Valeri A, Berthon P, Fournier G, Mangin P. Hereditary prostate cancer and other genetic predispositions to prostate cancer. Urol Int. 1998; 60:30-4.

6. Bruner DW, Moore D, Parlanti A, Dorgan J, Engstrom P. Relative risk of prostate cancer for men with affected relatives: systematic review and meta-analysis. Int J Cancer. 2003; 107:797-803. https://doi.org/10.1002/ijc.11466.

7. Stanford JL, Ostrander EA. Familial prostate cancer. Epidemiol Rev. 2001; 23:19-23.

8. Johns LE, Houlston RS. A systematic review and metaanalysis of familial prostate cancer risk. BJU Int. 2003; 91:789-94.

9. Lichtenstein P, Holm NV, Verkasalo PK, Iliadou A, Kaprio J, Koskenvuo M, Pukkala E, Skytthe A, Hemminki K. Environmental and heritable factors in the causation of cancer--analyses of cohorts of twins from Sweden, Denmark, and Finland. N Engl J Med. 2000; 343:78-85. https://doi.org/10.1056/NEJM200007133430201.

10. Eeles R, Goh C, Castro E, Bancroft E, Guy M, Al Olama AA, Easton D, Kote-Jarai Z. The genetic epidemiology of prostate cancer and its clinical implications. Nat Rev Urol. 2014; 11:18-31. https://doi.org/10.1038/nrurol.2013.266.

11. Frank C, Sundquist J, Hemminki A, Hemminki K. Familial Associations Between Prostate Cancer and Other Cancers. Eur Urol. 2017; 71:162-5. https://doi.org/10.1016/j. eururo.2016.07.031.

12. Chen YC, Page JH, Chen R, Giovannucci E. Family history of prostate and breast cancer and the risk of prostate cancer in the PSA era. Prostate. 2008; 68:1582-91. https://doi. org/10.1002/pros.20825.

13. Sellers TA, Potter JD, Rich SS, Drinkard CR, Bostick RM, Kushi LH, Zheng W, Folsom AR. Familial clustering of breast and prostate cancers and risk of postmenopausal breast cancer. J Natl Cancer Inst. 1994; 86:1860-5.

14. Thomas JA 2nd, Gerber L, Moreira DM, Hamilton RJ, Banez LL, Castro-Santamaria R, Andriole GL, Isaacs WB, $\mathrm{Xu}$ J, Freedland SJ. Prostate cancer risk in men with prostate and breast cancer family history: results from the REDUCE study (R1). J Intern Med. 1992; 272:85-92. https://doi.org/10.1111/j.1365-2796.2011.02504.x.

15. Rodriguez $\mathrm{C}$, Calle EE, Tatham LM, Wingo PA, Miracle-McMahill HL, Thun MJ, Heath CW Jr. Family history of breast cancer as a predictor for fatal prostate cancer. Epidemiology. 1998; 9:525-9. https://doi. org/00001648-199809000-00007.

16. Beebe-Dimmer JL, Drake EA, Dunn RL, Bock $\mathrm{CH}$, Montie JE, Cooney KA. Association between family history of prostate and breast cancer among African-American men with prostate cancer. Urology. 2006; 68:1072-6. https://doi. org/10.1016/j.urology.2006.06.028.

17. Beebe-Dimmer JL, Yee C, Cote ML, Petrucelli N, Palmer N, Bock C, Lane D, Agalliu I, Stefanick ML, Simon MS. Familial clustering of breast and prostate cancer and risk of postmenopausal breast cancer in the Women's Health Initiative Study. Cancer. 2015; 121:1265-72. https://doi. org/10.1002/cncr.29075.

18. Yu H, Frank C, Sundquist J, Hemminki A, Hemminki K. Common cancers share familial susceptibility: implications for cancer genetics and counselling. J Med Genet. 2016; 54:248-53. https://doi.org/10.1136/ jmedgenet-2016-103932.

19. Tulinius H, Egilsson V, Olafsdottir GH, Sigvaldason H. Risk of prostate, ovarian, and endometrial cancer among relatives of women with breast cancer. BMJ. 1992; 305:855-7.

20. Anderson DE, Badzioch MD. Breast cancer risks in relatives of male breast cancer patients. J Natl Cancer Inst. 1992; 84:1114-7.

21. Zheng G, Yu H, Hemminki A, Forsti A, Sundquist K, Hemminki K. Familial associations of male breast cancer with other cancers. Breast Cancer Res Treat. 2017; 166:897902. https://doi.org/10.1007/10.1007/s10549-017-4468-1.

22. Pritchard CC, Mateo J, Walsh MF, De Sarkar N, Abida W, Beltran H, Garofalo A, Gulati R, Carreira S, Eeles R, Elemento O, Rubin MA, Robinson D, et al. Inherited 
DNA-Repair Gene Mutations in Men with Metastatic Prostate Cancer. N Engl J Med. 2016; 375:443-53. https:// doi.org/10.1056/NEJMoa1603144.

23. Castro E, Goh C, Olmos D, Saunders E, Leongamornlert D, Tymrakiewicz M, Mahmud N, Dadaev T, Govindasami K, Guy M, Sawyer E, Wilkinson R, Ardern-Jones A, et al. Germline BRCA mutations are associated with higher risk of nodal involvement, distant metastasis, and poor survival outcomes in prostate cancer. J Clin Oncol. 2013; 31:174857. https://doi.org/10.1200/JCO.2012.43.1882.

24. Ostrander EA, Johannesson B. Prostate cancer susceptibility loci: finding the genes. Adv Exp Med Biol. 2008; 617:179 90. https://doi.org/10.1007/978-0-387-69080-3_17.

25. Langeberg WJ, Isaacs WB, Stanford JL. Genetic etiology of hereditary prostate cancer. Front Biosci. 2007; 12:4101-10.

26. Ewing CM, Ray AM, Lange EM, Zuhlke KA, Robbins CM, Tembe WD, Wiley KE, Isaacs SD, Johng D, Wang Y, Bizon C, Yan G, Gielzak M, et al. Germline mutations in
HOXB13 and prostate-cancer risk. N Engl J Med. 2012; 366:141-9. https://doi.org/10.1056/NEJMoa1110000.

27. Rochefort H. Endocrine disruptors (EDs) and hormonedependent cancers: Correlation or causal relationship? C R Biol. 2017; 340:439-45. https://doi.org/10.1016/j. crvi.2017.07.007.

28. Di Donato M, Cernera G, Giovannelli P, Galasso G, Bilancio A, Migliaccio A, Castoria G. Recent advances on bisphenol-A and endocrine disruptor effects on human prostate cancer. Mol Cell Endocrinol. 2017; 457:35-42. https://doi.org/10.1016/j.mce.2017.02.045.

29. Menegaux F, Anger A, Randrianasolo H, Mulot C, Laurent-Puig P, Iborra F, Bringer JP, Leizour B, Thuret R, Lamy PJ, Rebillard X, Tretarre B. Epidemiological study of prostate cancer (EPICAP): a population-based case-control study in France. BMC Cancer. 2014; 14:106. https://doi. org/10.1186/1471-2407-14-106. 